\title{
News and Views
}

\section{Science and Peace Problems}

During the National Peace Congress held in London on May 28-31, under the presidency of Dr. E. W. Barnes, Bishop of Birmingham, one of its commissions considered the attitude which members of the scientific and medical professions should adopt towards peace questions. The chairman, Prof. S. Chapman, who also gave the opening address in place of Prof. P. M. S. Blackett, who was absent through illness, advocated the establishment under international auspices of a world service of information on current events, as objective as possible, without comment or propaganda : controlled by a body of men chosen internationally according to some carefully devised scheme (like the judges of the Hague Court), for their personal qualities of judgment and impartiality; the daily bulletin being broadcast in the principal national languages, to provide men and women everywhere with a basis on which to form their political judgments. Dr. H. Joules and Dr. Howard Hughes described the organization and work of the Medical Peace Campaign.

THE meeting devoted much time to the discussion of the present rearmament programme; criticism was made of its exclusive emphasis on imperial defence rather than on collective security, and its execution by private firms for profit, without the safeguards recommended by the Royal Commission on Armament Manufacture. The official plans for air raid precautions were also discussed, and the experiments in progress by peace groups of scientific workers at Cambridge and Oxford, which question the efficacy of those precautions (see NATURE of April 10, p. 606). Mombers of these groups outlined the means which had been found effective in arousing interest among laboratory workers and maintaining discussion of peace. While it was judged unlikely that scientific workers would be able to reach common ground on the question whether or no they should participate in military preparation, tolerance between men taking different attitudes on this question was urged, and co-operation in peace work to the utmost possible extent. It should be made clear that men of science, in common with most members of the public, regard war as degrading to human progress as well as futile, and are willing to help in national and international work aimed at discovering and removing its causes and preventing its recurrence.

\section{Relations between Science and Philosophy}

THE fourteenth 'Unity School' organized by Mr. F. S. Marvin was held in the last week-end in May at Farnham Castle, and was a great success. The subject for discussion was the "Relations between Science and Philosophy", and as both sides were well represented and a large proportion of the disputants were fairly young people, the debates were as lively and vigorous as they were invariably friendly. Though it was remarked afterwards that there seemed little 'unity' in the arguments, it may well be that a perfectly frank statement of difference in an atmosphere of friendly feeling is the best way to reach a useful working agreement. There was certainly no attempt to set up any water-tight compartment for philosophic thinking on one side, or any rejection of the useful function of philosophy by the men of science on the other. The only body of people who seemed to stand isolated and not acceptable to either side were the 'logical positivists'. But Wittgenstein was only a name-if so much-to most of the audience, and further investigation was clearly necessary.

ON the side of science, the most novel and striking contribution was made by Dr. Redcliffe Salaman, director of the Potato Virus Research Station at Cambridge. His demonstration of the infinitesimal size of these organisms introduced one into a region where vital and inanimate objects seem to exist indistinguishably side by side. He gave full details of the discoveries which have lately been made in this sphere in the United States, especially by Stanley. A full and useful discussion followed as to the nature and working of the protein crystalloid bodies now revealed in certain viruses. It turned largely on matter which has been communicated to NATURE, and left many of the audience wondering whether in these crystals something has not been found which is an actual link between living and non-living. It was decided at the close of the proceedings to continue the series of 'Unity Schools' on somewhat similar lines next year. Mrs. Innes, of Coneydale, Welwyn Garden City, will be glad to answer any inquiries. Contact between the various branches, especially of physical and social science, was felt to be the most useful line of approach to 'unity' at the present time.

\section{Total Solar Eclipse of June 8}

From Press reports, it appears that the total eclipse of the sun was observed under perfect conditions on June 8 at Canton Island in the South Pacific, where the American expedition organized by the U.S. Naval Observatory and the National Geographic Society of Washington had established its stations (see Nature, April 24, p. 698). The Daily Telegraph, in co-operation with the National Broadcasting Company of America, arranged for Prof. A. Fowler to speak from a studio in Broadcasting House, London, to leading astronomers observing the eclipse on Canton Island, and the conversation is described in the issue of June 9 . It appears that many photographs were taken, and that the corona, as was expected, was of the type of maximum solar activity. 
The spectroscopic programme also seems to have been carried out successfully. The Daily Telegraph is to be congratulated upon its enterprise in obtaining direct information by radio of observations of an eclipse from a station more than 9,000 miles away. This very remarkable achievement merits a place in astronomical history.

\section{Blood Groups in Africa}

At the beginning of April, Dr. Ronald Elsdon-Dew and Mr. J. de Bruijne, of the South African Institute of Medical Research, left Johannesburg on a prolonged tour of investigation of the blood groups of African peoples, and more especially of the Bantu. They propose to examine various tribes in Southern and Northern Rhodesia, Nyasaland, Tanganyika, Kenya, the Anglo-Egyptian Sudan, Uganda and the Belgian Congo. Dr. Elsdon-Dew, who holds the appointment of assistant pathologist in the Medico-legal Department of the South African Institute of Medical Research, has been engaged on an intensive study of the African blood-groups since 1932, and has examined the blood grouping of more than five thousand South African Bantu. In publishing his results, and the somewhat startling inferences as to the racial history of Africa to which in his opinion they appeared to point, he emphasized the fact that theorizing on the serology of African peoples must of necessity be tentative, for in this respect Africa is still the Dark Continent. The present expedition has been undertaken to remedy the lack of material for purposes of comparison which gave to his ethnological argument a highly speculative character, more especially as regards the existence of a hypothetical primitive black race, possessing neither the $A$ nor the $B$ groups, to which his results appeared to point, and with which, serologically, the Southern Bantu apparently showed a closer affinity than any other people of which the blood groups were known. The expedition, which is travelling by motor caravan, will be at work for about six months.

\section{Local Archæological Studies in Nottingham}

Publication of the first annual report of the Excavation Section of the Thoroton Society of Nottinghamshire falls opportunely at a moment when attention has been directed in Parliament to the opportunity open to local archæological and scientific societies to educate their neighbours, the local authority and the local public generally, as to the desirability of preserving for posterity buildings and erections of historical or æsthetic interest and places of natural beauty (see Nature, Feb. 27, p. 345). The Excavation Section of the Thoroton Society has been formed as an outcome of the enthusiasm of a small number of students of the past history of the city of Nottingham, but more especially through the efforts of Mr. G. F. Campion, who was anxious that the work of local excavation carried out by himself and his father before him over a number of years should be placed on a permanent footing. Very wisely it was decided not to form a new society for this purpose, but to join forces with the Thoroton
Society, the long-established centre of archæological and antiquarian interest in the county. Thus the activities of the newly established section will be directed not only to continuing the work of excavation, but also to the expert examination and record of the numerous evidences of the city's past cultural history which are being brought to light with increasing frequency in the building operations in progress in connexion with the improvement and enlargement of business and other premises in Nottingham. It should at least be able to ensure that nothing worthy of note is overlooked-a matter of much importance in an area like Nottingham which is honeycombed with underground caves. The record of the first year's operations covers not only the excavations in Notting. ham's Norman and Plantagenet castle, and a Roman fortress, but also the supervision of excavations for building operations on eight sites, which produced some interesting samples of medieval pottery, including a fabric unknown from any other area and thought to be an exclusive product of Nottingham.

\section{Miocene Implements}

A NUMBen of years ago, the late Mr. Edward Westlake collected a very large series of specimens of flaked chert and flint from upper Miocene deposits at Aurillac, and other sites, in the Cantal, France. These specimens, which number several thousands, are now housed at the Museum, Ipswich, where they are being studied by Mr. Reid Moir. When his exam. ination of the collection is completed, Mr. Reid Moir proposes to describe it; but it may be said that a great many of the specimens exhibit, in a marked degree, certain characteristics which have been generally accepted as indicative of artificial shaping. Archæologists, and those interested in the antiquity of man, owe a debt of gratitude to Mr. Westlake's insight and care in getting together such a vast and important collection, which, from many aspects, is unique. There would seem to be no doubt as to the Upper Miocene age of the deposits from which the specimens were derived, and their adequate descrip. tion may well prove to be a significant contribution to the solution of the problem of the antiquity of the human race.

\section{Dry Crossings of the Nile}

With reference to the two letters to the Editor in Nature of June 5, p. 961, under the title "Dry Crossings of the Nile", from E. J. Wayland and Dr. H. E. Hurst, we have received the following from Dr. A. E. H. Tutton: "It may be of interest to add to the record of the observations by Dr. Wayland, from the air in 1930 and by an actual passage on foot in 1933, that a natural bridge does from time to time exist across the higher reaches of the Nile, strong enough to bear the elephant, a still more remarkable observation by my late brother-in-law, Mr. Leonard Loat, made and recorded by him in the year 1902, during his survey of the fishes of the Nile for Lord Cromer's Government and the British Museum (Natural History). In a letter to me 